\title{
War and Elections*
}

\author{
DANiel STEVEnS \\ University of Exeter
}

\begin{abstract}
This paper argues that the effects of war as a performance issue in elections are different for a right-wing than a left-wing leader. War is consistent with the reputation of right-wing, hawkish governments, but does not fit the reputation of leftwing, dovish governments, and necessitates a turn away from the domestic issues the public expects left-wing governments to prioritize. War therefore varies in its effects on perceptions of right-wing and left-wing leaders. War also provides more temptation for left-wing supporters to defect to the incumbent under a right-wing government than for right-wing supporters to defect under a left-wing government. The War in Iraq and elections in the United States and UK provide a unique case to test these arguments. The results confirm that Blair paid a higher political price as a left-wing leader, because perceptions of Blair's trustworthiness became central to evaluations of him. Conversely, positive perceptions of strength became central to evaluations of Bush as a right-wing leader. The war also had asymmetric effects on supporters of the opposition party in the UK that resulted in higher costs to Blair. These findings imply that the risks of going to war are greater for left-wing leaders.
\end{abstract}

This paper examines the impact of war on elections. Much of what we know about public opinion, voting behavior, and war comes either from single country studies of particular conflicts (for example, Vietnam, the Falklands, the Gulf War), or from studies that pool multiple conflicts across many years. The former preclude separating country effects from the characteristics of the war, of time, or of the incumbent government, while the latter focus on war duration, war outcomes, and the fates of regimes and leaders, rather than on the content of public attitudes (Bueno de Mesquita, Siverson and Woller 1992; Chiozza and Goemans 2004; Debs and Goemans 2010; Croco 2011). Thus, while some research theorizes about public opinion and voting behavior across several wars (for example, Berinsky 2009), we know little about the generalizability of findings.

To leverage these issues, this paper uses a comparison of the same war, at the same time, in two countries. It takes advantage of the unique fact that the War in Iraq as an ongoing conflict was closely identified with the tenures of George W. Bush and Tony Blair as they sought reelection in the United States and the UK within 6 months of each other. I show that perceptions of the War in Iraq factored in each election, confirming the generalizability of Berinsky's (2009:9) claim that war operates as a "performance issue" in elections, much like domestic considerations of performance such as the economy. In addition, this paper illustrates how the reputation of a party as hawkish or dovish, in conjunction with differences in party coalitions, may produce different political costs for right-wing and left-wing incumbents.

Daniel Stevens is an associate professor of politics at the University of Exeter. His work has appeared in the American Journal of Political Science, Journal of Politics, Political Research Quarterly, and British Journal of Political Science. He is currently working on a book (with Nick Vaughan-Williams, University of Warwick) on perceptions of security threats in Britain (forthcoming with Manchester University Press).

* Thanks to members of the Politics seminar at the University of Kent, particularly Matt Loveless, and to Susan Banducci, John Transue, and Jeffrey A. Karp for helpful comments and suggestions. This paper was completed while I was a visiting professor at the Australian National University.
These findings extend arguments about the similarity of domestic and foreign policy influences on voting behavior beyond the United States. By using a comparative approach, they also broaden Berinsky's parallel with domestic policy further. Just as right-wing and left-wing governments have coalitions with respect to economic policy (Alvarez, Garrett and Lange 1991; Garrett 1998), right-wing and left-wing governments have different expectations and different coalitions when it comes to war. This implies that war has different effects on perceptions of right-wing and left-wing leaders. By examining the indirect effects of war via perceptions of incumbent leaders' qualities, this article also provides new evidence on how conflict differently affects evaluations of a dovish party leader than a hawkish party leader. As a result of these factors, going to war appears riskier for the re-election of a left-wing incumbent leader than for a right-wing incumbent leader.

\section{War, Public Opinion, and Elections}

\section{Previous Research}

How do wars affect public opinion, voting behavior, and elections? They clearly can have an impact. ${ }^{1}$ On the negative side of the ledger, Cotton (1986:633) examines five wars American leaders fought and refers to "the historical record of voter punishment," while Bueno de Mesquita et al. (1992:640) refer to losses that are "likely to be more dramatic and more apparent to the domestic population than is evidence of the failure of economic policies" (see also, Croco 2011). On the other hand, Pan and Kosicki (1994:121) write of the George H.W. Bush presidency that, "The Gulf crisis issue defined the presidency [positively] in voters' minds during this period."

\footnotetext{
${ }^{1}$ Although Chiozza and Goemans (2004), and Debs and Goemans (2010) do not find that wars systematically affect the chances of removal from office in presidential or parliamentary democracies. On the other hand, Croco (2011), among others, argues that war outcomes have an impact but they affect culpable and nonculpable leaders differently.
} 
Norpoth (1987) argues that the Falklands conflict boosted the popularity of the Thatcher government and ultimately added five points to the Conservative Party vote in the election that took place almost a year later, while Lanoue and Headrick (1998) argue for a similar impact of the Falklands War, but one mediated by the popularity of Thatcher herself in the wake of the conflict. $^{2}$ One explanation is simply that international conflicts receive prominent media coverage. Such agenda-setting effects mean they are regarded as salient issues. Extensive coverage also primes the public to weigh considerations of conflicts heavily in their evaluations of the incumbent and his or her government (for example, Krosnick and Brannon 1993; Pan and Kosicki 1994; Parker 1995).

Early research suggested two tendencies: first, an initial "rally round the flag" effect, then growing weariness with war and negative effects on support for the incumbent government as casualties mount (Mueller 1971, 1973). The research that followed sought to explain rally round the flag effects more fully, while also questioning the notion of a straightforward relationship between public opinion and casualties. Thus, rallies seem to result from the elite consensus that generally follows the outbreak of war and related one-sided messages transmitted through the news media (Baum 2002). The causes of the tendency for public support to wane have provoked greater disagreement, however. In what Berinsky characterizes as "event-response theories," some authors continue to echo Mueller in arguing that public opinion responds to the number of casualties in conflicts, although the relationship is more nuanced. For example, Gelpi, Reifler and Feaver (2007) argue that tolerance of casualties depends on perceptions of the likely success of a mission, implying that an optimistic public increases its support for war in the face of rising casualties, while for a pessimistic public, such casualties are associated with a drop in support. Larson (1996) contends that public tolerance for casualties rests on the consensus among elites about their own tolerance of casualties. Such accounts represent a view of public opinion Jentleson's (1992) “pretty prudent public" best encapsulates.

Berinsky (2009), however, disputes these accounts. He contends that partisanship strongly colors perceptions of war, even of "objective facts" such as the number of casualties. The parallels between public opinion on domestic issues and public opinion on foreign policy are much closer than has been appreciated heretofore. Thus, wars influence the public - and elections - as a "performance issue." Like an economic indicator such as growth in GDP, they reflect on the overall competence of an incumbent government, but there is bias in perceptions of those indicators. Wars also elevate the importance the public places on qualities of leaders such as strength and charisma (Merolla and Zechmeister 2009).

In these accounts, elite cues and partisanship affect perceptions of performance and of leadership. But Koch and Sullivan's (2010) depiction of partisan effects suggests a wrinkle to the way in which partisanship

\footnotetext{
${ }^{2}$ Disputes arise over how long the effects last once a conflict ends, however (for example, Norpoth 1987; Sanders, Ward and Marsh 1987; Clarke, Mishler and Whiteley 1990). It also appears that the Gulf War did not help George Bush (Parker 1995) or John Major (Sanders 1993) in their 1992 elections, though Croco (2011:460) argues that the public transfers responsibility to a new leader from the same party "with minimal, if any, discounting" and that culpable leaders who lose wars are more likely to be removed from office.
}

influences the impact of war as a performance issue. They argue that the partisanship of a government affects its willingness to bear the costs of continuing a conflict: Right-wing, more hawkish, governments are more willing to sustain conflicts than left-wing governments because the costs in domestic support are higher for left-wing governments, whose supporters tend to prioritize domestic concerns such as welfare and employment, than for rightwing governments, whose supporters tend to prioritize national security and defense. ${ }^{3}$ This means that right-wing leaders become more likely to continue conflicts in the face of public disapproval while left-wing leaders become more likely to end them. ${ }^{4}$

With respect to public opinion and elections, this implies that partisanship does not simply bias perceptions of war as a performance issue. Rather, just as partisans have different expectations of parties' economic priorities in government (Alvarez et al. 1991; Garrett 1998), there are different expectations for right-wing and left-wing governments when it comes to war. Because voters also tend to "rely on processes of classification" (Rahn 1993:472), as "theory-driven" processors drawing on longestablished party stereotypes, when an incumbent party bucks that reputation or stereotype the effects on the public are unlikely to be the same as when an incumbent party acts in ways that are consistent with its reputation. ${ }^{5}$ It is an open question as to how these different effects may manifest themselves, however. The relevance of war may simply diminish for evaluations of left-wing governments, the effects of war on perceptions of leadership qualities may differ for left-wing leaders, or a combination of such effects could contribute to left-wing governments incurring higher costs and lesser gains for going to war.

In sum, we know that wars affect public opinion due to factors such as their prominence in media coverage, elite cues, and as indicators of a government's competence. They also affect elections, although the nature of those effects depends on whether the conflict is ongoing, as in Vietnam in the 1968 US election, or Iraq in 2004 in the United States and 2005 in the UK, or has ended, like the Falklands War in 1983 and the Gulf War in 1992. ${ }^{6}$ Previous research, however, at most examines the effects of different wars in elections in single countries but not the same war in different countries. This makes it difficult to separate the generalizable effects of wars on voting behavior from other factors such as the effects of the characteristics of different conflicts, incumbency, time, and, of particular importance to this paper, the hawkish or

${ }^{3}$ I assume that right-wing governments tend to be more hawkish, along with authors such as Berinsky (2009:285) and Koch and Sullivan (2010).

${ }^{4}$ Trager and Vavreck (2011) also consider partisanship and argue the opposite - that left-wing (Democrat) leaders may benefit in terms of approval by bucking stereotype and fighting wars, even those they do not win. But a key difference with claims such as mine (and Koch and Sullivan's) is that their experiments do not incorporate the guns versus butter trade-offs that affect partisans differently. As Bueno de Mesquita et al. (1992:638) put it, "every foreign policy maker must look over his or her shoulder and contemplate the prospective domestic political risks associated with each foreign policy action." I argue that those risks are asymmetric.

${ }^{5}$ Foreign policy also prompts more reliance on the heuristic of partisan stereotypes (Baum and Groeling 2009).

${ }^{6}$ In support of this, public opinion researchers such as Norpoth (1987) show that the effects of wars on the public decay over time. On the other hand, Croco (2011) suggests that it is immaterial whether or not a war has ended prior to an election. However, Croco does not compare the effects of ongoing wars with wars that have ended; she only looks at wars that have ended. 
dovish reputation of the incumbent party of government. ${ }^{7}$ Ideally, one therefore wants to compare the effects of the same war in elections in more than one country, with incumbent parties with different reputations, and preferably with the war ongoing. ${ }^{8}$ The War in Iraq provides such a case. ${ }^{9}$

\section{The War in Iraq, the War on Terror, and the Elections of 2004} in the United States and 2005 in Britain

The War in Iraq offers a unique combination of factors that makes comparison particularly appropriate: the personal association of both incumbent leaders with the decision to go to war, ${ }^{10}$ the absence of a coalition that went much beyond their two countries, and the fact that both incumbents fought elections within 6 months of each other while the war was still ongoing. While similar, the first Gulf War was not personally associated with Prime Minister John Major-it was Margaret Thatcher who initially committed British forces-the coalition went well beyond the two countries, and the conflict had long since ended by the time of the 1992 elections. Similarly, during the Second World War, there were elections in the United States in 1944 and in Britain 6 months later, but the war was over in Europe when the British election took place, a broad coalition of nations opposed to the Axis powers existed, and the British election did not involve the prime minister who had first made the decision to declare war. ${ }^{11}$

It could be argued, however, that the United States and Britain are too different to provide a valid comparison of the effects of war, particularly because one system is presidential and the other parliamentary. ${ }^{12}$ But that ignores long-term trends in the presidentialization and personalization of British politics and British political campaigns (Mughan 1993). Indeed, Stewart and Clarke (1992) suggest that leaders' images may be more powerful influences on the vote than issues and that competence and responsiveness are particularly important qualities in British elections, just as in the United States

\footnotetext{
7 Scholars of international relations routinely examine multiple wars spanning centuries (Gaubatz 1991; Bueno de Mesquita et al. 1992; Chiozza and Goemans 2004; Debs and Goemans 2010; Croco 2011). However, their interests are in war onset, duration, and outcomes, and the impact on regime change (see also, Stanley 2009) - comparing democracies and nondemocracies, for example-rather than in how wars affect perceptions of leaders and voting behavior.

${ }^{8}$ Thus avoiding questions of the patterns of decay in effects of a conflict after it ends.

${ }^{9}$ Most studies of the impact of war also focus on approval of leaders rather than elections. While conflicts affect approval of leaders, and thus aspects of governance such as the ability to pass legislation, we can be certain that the $90 \%$ approval rating enjoyed by George W. Bush in the wake of $9 / 11$ or the $89 \%$ approval rating of his father due to the first Gulf War would not have translated directly to the ballot box. It is crucial to understand the impact of war on this most important of decisions.

${ }^{10}$ Mueller (2005:119) describes the UK as America's "only notable ally" and says that "Bush and Blair fabricated a rather small and personalized 'coalition of the willing."

11 Once again, Croco's (2011) research suggests that both Churchill and Major were culpable leaders, but she focuses on war outcomes and whether or not a leader was removed as a result, rather than war's impact on perceptions of leaders and how these feed into voting behavior. Her analysis also assumes the same risk of punishment for left- and right-wing leaders.

${ }^{12}$ Although Berinsky (2009) discusses the 1945 election in Britain, which suggests he regards it as a comparable case to those he examines from the United States and, as I have indicated, IR scholars regularly compare the fates of leaders in democracies and nondemocracies over multiple conflicts and hundreds of years.
}

(see also, Stevens and Karp 2012). The effects of war on leaders' images also appear similar. Clarke et al. (1990), for instance, argue that the Falklands War both directly and indirectly affected government popularity via "altered public judgments about her [Thatcher's] competence as prime minister" (80, my italics).

Other potentially salient differences, however, pertain specifically to the validity of the comparison of public opinion and the War in Iraq. The conflict, for example, was precipitated by the September 11th attacks, which occurred on American soil during Bush's tenure. However, this underestimates the impact of $9 / 11$ on Britain. More Britons died in the attack than in any of the IRA terrorist incidents of the previous three decades; indeed, more died in the $9 / 11$ attacks than would die on $7 / 7$. Furthermore, the media covered $9 / 11$ and the ensuing war on terror and War in Iraq extensively and was criticized for many of the same biases as the US media (Miller 2004). It could also be objected that while the United States could have fought the war without the UK, the reverse could not have happened. However, this overemphasizes the degree to which the War in Iraq was purely about military capability. As Wesley Clark put it, "this war will ultimately prove to be as political as it is military...And here the Prime Minister is likely to prove, again, the indispensable ally."13

Bush and Blair's approval ratings provide a concrete piece of evidence that speaks to the validity of the comparison. If the publics in the two countries experienced 9/11 and the Iraq War similarly, their leaders' approval ratings should respond similarly to the onset of war and its aftermath. Figure 1 presents approval of the two leaders from the first polls after 9/11 until Blair's re-election in May 2005 and shows that they tracked each other remarkably closely. ${ }^{14}$ The two series correlate at .88 . We only see divergence in movement at the beginning and end of the series: At the beginning because the initial bounce in approval that Blair received after $9 / 11$ faded much faster than the bounce that Bush received, and at the end of the series when Blair's popularity grew as the British election approached while approval of Bush fell. Perhaps Bush's and Blair's approval ratings were always in lockstep, even before $9 / 11$. If we look at approval for the 8 months between Bush's inauguration and September, however, Bush and Blair's ratings were negatively correlated. ${ }^{15}$ In sum, Figure 1 provides strong support for the validity of comparing the impact of the War in Iraq on the two elections.

Another potentially salient difference is that the broader war on terror received more emphasis from the Bush administration than from the Blair government, possibly insulating the American public's approval of the broader war from events in Iraq. This also implies that the British public would be less likely to see a distinction between the war on terror and the War in Iraq. However, Table 1 contradicts this argument. It presents approval of the War in Iraq and the war on terror, in total and split

\footnotetext{
13 The Times, March 27, 2003, "Bush must look beyond this war even before it ends"

14 I adjusted the two scales, plotting the series on two different $y$-axes, because the equilibrium position of the British public seems to be a higher level of dissatisfaction than in the United States. Whereas American presidents rarely experience approval ratings in the 20s, all four British prime ministers regularly experienced such satisfaction ratings, with Major's dipping as low as 17.

${ }^{15}$ I also looked at consumer sentiment. The economic series were correlated at .6 , a fairly strong relationship but nothing like the approval ratings of the two leaders.
} 


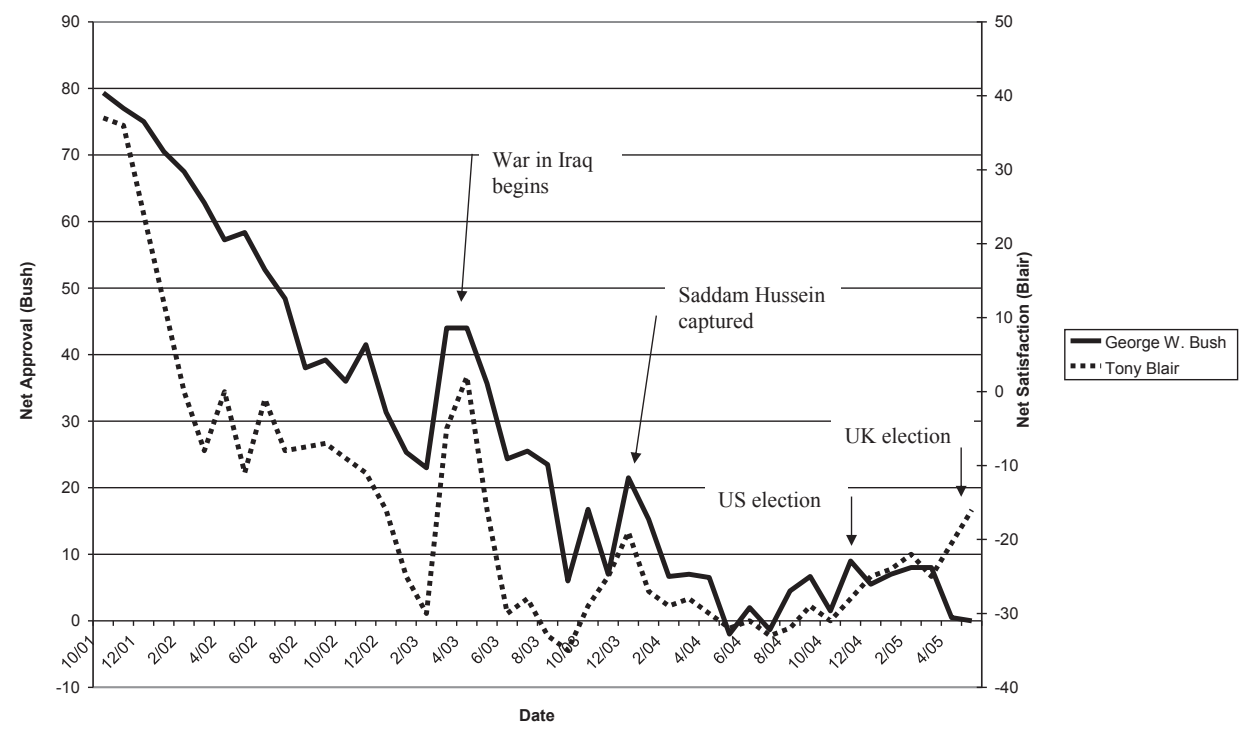

Fig 1. Approval/Satisfaction with George W. Bush and Tony Blair from October 2001 to May 2005 Source: Gallup presidential approval ratings (US), MORI prime ministerial satisfaction ratings (UK).

TABLE 1. Approval of the War in Iraq and the War on Terror

\begin{tabular}{|c|c|c|c|c|c|c|c|c|}
\hline & \multicolumn{8}{|c|}{ War in Iraq } \\
\hline & \multicolumn{2}{|c|}{ Total } & \multicolumn{2}{|c|}{ Republican identifier } & \multicolumn{2}{|c|}{ Independent } & \multicolumn{2}{|c|}{ Democrat identifier } \\
\hline & Approve & Disapprove & Approve & Disapprove & Approve & Disapprove & Approve & Disapprove \\
\hline \multicolumn{9}{|c|}{ (a) United States (numbers are \%) } \\
\hline \multicolumn{9}{|c|}{ War on terror } \\
\hline Approve & 40 & 14 & 76 & 13 & 33 & 20 & 11 & 14 \\
\hline Disapprove & 3 & 43 & 4 & 8 & 2 & 45 & 2 & 73 \\
\hline
\end{tabular}

War in Iraq

\begin{tabular}{|c|c|c|c|c|c|c|c|}
\hline \multicolumn{2}{|c|}{ Total } & \multicolumn{2}{|c|}{ Labour identifier } & \multicolumn{2}{|c|}{ Conservative identifier } & \multicolumn{2}{|c|}{$\begin{array}{l}\text { Liberal Democrat } \\
\quad \text { identifier }\end{array}$} \\
\hline Well & Badly & Well & Badly & Well & Badly & Well & Badly \\
\hline
\end{tabular}

(b) Britain (numbers are \%)

War on terror

\begin{tabular}{lrrrrrrrr} 
Well & 15 & 16 & 30 & 19 & 8 & 12 & 6 \\
Badly & 2 & 32 & 1 & 14 & 4 & 44 & 18 \\
\hline
\end{tabular}

(Note. Percent do not add to 100 because the answers "neither well nor badly" are excluded from the table.

Shaded values highlight respondents who were positive about the war in Iraq but negative about the war on terror, or were positive about the war on terror but negative about the war in Iraq.)

by party identification, from the 2004 American National Election Study (ANES) and 2005 British Election Study (BES) (instead of Independents the table for Britain includes Liberal Democrat identifiers, whose party had opposed the War in Iraq). While the measures of approval are not identical, most striking is the similarity of the proportions of respondents in the shaded off-diagonals - those approving of the war on terror and disapproving of the War in Iraq or vice versa. ${ }^{16}$ Indeed, the

\footnotetext{
${ }^{16}$ In Britain, the measure is of the Labour government's handling of the situation in Iraq and its handling of the risk of terrorism, on a scale from "very well" to "very badly," including an option of "neither well nor badly," which I exclude from Table 1. In the United States, the questions refer to approval of Bush's handling of the wars and have no midpoint. For shorthand, I generally describe responses that the Labour government had handled the War in Iraq or war on terror well as "approval" and badly as "disapproval."
}

proportions are, if anything, marginally larger in Britain. The correlation between approval of the war in Iraq and perceptions of the war on terror was stronger in the US election, at .74, than in the UK election, where it was .51, suggesting that the American public distinguished the two wars somewhat less than the British.

To be sure, extant research has already tried to gauge the effects of the War in Iraq on these elections. However, none of this research compares the two elections and few of the studies consider the effects of the war within broader theories of the impact of war on public opinion and elections. The bare facts of the two elections offer interesting contrasts. Although Labour won an unprecedented third term in Britain, it captured only $35 \%$ of the vote on a weak turnout, a drop of 5 points in support from 2001. Its majority in the House of Commons was also reduced by one hundred seats. While 
the vote share of the Conservative Party was also unimpressive, the third party, the Liberal Democrats, who consistently opposed the war, gained four points during the campaign and finished with a relatively high $22 \%$ of the vote, and the combined vote for minor parties, the highest on record, was apparently due to "immigration, Iraq, and Europe" (Webb 2005:119). In contrast, George W. Bush increased his number and share of the votes from 2000 on a higher turnout, became the first candidate for president to secure a popular majority of votes for sixteen years, and, unlike any of his post-New Deal Republican predecessors, was re-elected with Republican majorities in both houses of Congress. On the other hand, the election was closer than any of the previous incumbent victories in the post-World War II era.

Most research on the 2004 election in the United States agrees that the War in Iraq was a drag on support for George W. Bush but argues that some combination of factors limited its damage. For example, Abramson, Aldrich, Rickershauser, and Rohde (2007:218) write that "voters were mainly influenced by three main dimensions of presidential performance: the war on terror, the war in Iraq, and the economy. The first benefited Bush, while the last two worked against him." However, studies make different arguments about the factors that moderated the cost of the war on support for Bush. Namely, that voters were more positive about the broader war on terror (Gershkoff and Kushner 2005; Lewis-Beck, Jacoby, Norpoth and Weisberg 2008) that they stemmed from the effects of perceptions of Bush's qualities as a strong and decisive leader (Lewis-Beck et al. 2008), attributes on which his image had improved as a wartime president, or, instead, from the insulating effects of the War in Iraq on unfavorable evaluations of the economy (McAllister 2006).

With the British election of 2005, there is consensus that the Iraq War cost the Labour party votes, partly by diminishing perceptions of Blair's character. Tony Blair did not enjoy the same level of unity within his own party as Bush. Cabinet member and former foreign secretary Robin Cook resigned, along with two less prominent members of the government. Moreover, the House of Commons vote witnessed the largest rebellion among the backbenchers of a majority party since the repeal of the Corn Laws in the mid-19th century. Just $56 \%$ of the British public backed the war in Iraq when it began, even with a rally effect. In addition, the British media questioned the justification for the war (Goddard, Robinson, and Parry 2008).

As in the United States with Bush, Iraq was very much associated with Blair as an individual. Clarke, Sanders, Stewart, and Whiteley (2009:53-4) argue that, "the interminable, bloody conflict in Iraq damaged Prime Minister Blair's reputation as a competent and trustworthy leader...[and] had important consequences for the decline in Labour support that occurred between 2001 and 2005." As in some of the accounts of the 2004 US election, Clarke et al. (2009) contend much of the impact was indirect, mediated via Blair's image. They find direct effects of the War in Iraq on feelings toward Blair, and effects of feelings toward Blair on voting Labour, but no direct effects of evaluations of the war on voting Labour. ${ }^{17}$

\footnotetext{
${ }^{17}$ Despite the evidence in Table 1, narratives and analysis of the UK election do not include the notion that the British public made any meaningful distinction between the war on terror and the War in Iraq.
}

\section{Hypotheses}

The hypotheses that follow examine the basic question of war as a performance issue in elections but also several testable implications of the theory that left-wing governments risk paying a higher price, using the War in Iraq as a case. I test them with data from the 2004 American National Election Study (ANES) and the 2005 British Election Study (BES) rolling cross-section surveys, described in detail in the next section.

If publics use wars as indicators of performance, their impact on evaluations of leaders should vary little between Britain and the United States. Thus:

H1a: By influencing perceptions of a government and its leader's performance, there should be similar effects of the War in Iraq on perceptions of the qualities, and on overall evaluations, of Bush and Blair.

"Similar effects" mean that the approval of the War in Iraq should have independent and positive effects on perceptions of both leaders. The size of effects need not be the same in the two elections, but the direction of effects in both elections should be positive and statistically and substantively significant.

As mentioned above, however, another possibility is that war is discounted as a performance issue in evaluations of left-wing governments:

H1b: Because of expectations that left-wing governments prioritize domestic concerns such as welfare and employment, the War in Iraq should have little impact on perceptions of the qualities, and on overall evaluations, of Blair.

This implies that the effects of the War in Iraq in Britain should clearly be smaller than those in the United States. "Clearly smaller" effects cannot be ascertained with a statistical test, but statistical insignificance, or substantively minor effects in Britain, is taken as evidence of "little impact" and thus as support for H1b over H1a. ${ }^{18}$

Yet, a further possibility suggested by partisan stereotypes (Rahn 1993) and by Koch and Sullivan's (2010) research is that war as a performance issue affects perceptions of the qualities of leaders similarly but differences emerge because war primes different attributes of leadership in overall evaluations of left-wing and right-wing leaders.

H2: By acting in ways that are consistent with their party's reputation, right-wing leaders enhance the influence of perceptions of their strength, whereas for left-wing leaders, by bucking reputation, war enhances the influence of perceptions of attributes such as trust. Such attributes assume added salience in overall feelings toward leaders.

Support for $\mathrm{H} 2$ therefore requires two findings: statistically significant relationships between the War in Iraq and perceptions of Bush's strength in the United States and Blair's trustworthiness in Britain that are similar to perceptions of other attributes, and evidence that these perceptions weighed more heavily in overall evaluations of the leaders, which would be shown by statistically significantly larger effects of these leadership qualities than

\footnotetext{
${ }^{18}$ Left-wing leaders could also benefit more in the public eye by bucking the party stereotype (Trager and Vavreck 2011). However, as the hypothesis implies, I consider this unlikely because the decision to go to war involves costs in terms of domestic priorities.
} 
of others such as knowledge in the United States or responsiveness in Britain.

A third possibility is that wars are weighted similarly as performance issues for left-wing and right-wing leaders, but right-wing governments ultimately receive greater reward at the ballot box among those approving of a war. Under right-wing governments right-wing supporters who approve of a war have little temptation to defect from their party, while left-wing supporters who approve of a war will be tempted not to vote for their party and to reward the more hawkish incumbent government. The reverse is less likely: Under left-wing governments, right-wing supporters who approve of an ongoing war have less reason to defect to the more dovish party. This implies that:

\section{H3: Right-wing governments reap a higher reward in terms of vote preferences among those approving of a war than left-wing governments.}

This hypothesis would be supported if the impact of approval of the War in Iraq on vote choice benefited Bush to a greater extent than it did Blair and the Labour Party.

In addition, left-wing governments may pay a higher price in terms of the likelihood of approval of war in the first place among their own supporters.

H4: Supporters of left-wing governments are more likely to disapprove of a war than supporters of rightwing governments.

To be sure, the options available to British voters differed in the important respect that they could vote for a third party, the Liberal Democrats, which had opposed the war-the Democrats and the Conservatives were similar in that both had initially supported the war. However, this does not affect $H 3$ because it concerns the behavior of those who approved of the war, for whom the Liberal Democrats would not be an attractive choice. ${ }^{19}$

\section{Data and Analysis}

I use data from the 2004 ANES, a two-wave pre- and postelection survey, and the 2005 BES rolling cross-section survey, a three-wave panel with a precampaign survey, a campaign survey administered in the 4 weeks before the day of the election on May 5 , and a postelection survey. ${ }^{20}$ Enhancing the validity of comparison requires variables and measures that are as similar as possible. Both surveys asked about perceptions of the War in Iraq and the war on terror. The ANES asked about approval of Bush's handling of each on a four-point scale from "strongly approve" to "strongly disapprove", that is, there was no midpoint, while the BES gauged perceptions of the incumbent government's handling of the War in Iraq and the war on terror on 5-point scales from "very well" to "very badly." ${ }^{11}$ Both surveys also asked about

\footnotetext{
${ }^{19}$ Models that excluded Liberal Democrat voters, or excluded Liberal Democrat voters and Liberal Democrat identifiers, did not affect any of the substantive findings and only strengthened support for H3. Results are available from the author on request.

${ }^{20}$ The BES rolling cross-section includes the requisite questions about the War in Iraq and perceptions of various leadership qualities. The sample was drawn from an internet panel (see Sanders, Clarke, Stewart, and Whiteley (2007:257) for evidence that the in-person and internet surveys "tell very similar stories about what matters for turnout and party preference in Britain").

${ }^{21}$ Neither survey included questions on retrospective and prospective judgments of the war but "approval" likely incorporates considerations of both.
}

perceptions of the economy in terms of approval of each incumbent government's handling of the economy. ${ }^{22}$

The other element of war as a performance issue is its effects on perceptions of leaders and their qualities. The ANES asked about Bush and Kerry's honesty, strength, morality, knowledge, caring for other people, and about respondents' overall feelings toward the two leaders. The BES asked about the party leaders' competence, responsiveness, trustworthiness, and overall feelings toward them. Thus, the qualities surveyed are not exactly the same, but there are parallels between honesty (ANES), morality (ANES), and trustworthiness (BES), and caring for other people (ANES) and responsiveness (BES), while knowledge (ANES) is likely to be a component of perceptions of competence (BES). The BES survey does not contain measures of perceptions of leaders' strength, but I include it in the US model nevertheless because of its importance in accounts of how the public can respond to wars. Overall, the data allow comparison of the impact of war on feelings toward leaders and of evaluations of leaders on vote choice. $^{23}$

Previous research suggests a "funnel of causality" from perceptions of war, to perceptions of the qualities of leaders, to overall evaluations of leaders, and to vote choice. Structural equation models (SEM) are optimal because they allow estimation of the relationships simultaneously, of the overall model fit, and, where specified, separation of a variable's impact into direct and indirect effects. I use SEM estimates to test $H 1$ to $H 3$. Figure 2 depicts the basic model. ${ }^{24} \mathrm{H} 4$ is tested through bivariate tables.

To reiterate, the models incorporate variables that are as similar as possible. The main exogenous variable is approval of the War in Iraq, with controls for approval of the war on terror, approval of the economy, and party identification. ${ }^{25}$

\footnotetext{
${ }^{22}$ I focus on approval of the government's handling of the economy rather than retrospective or prospective evaluations for purposes of comparison with the questions about approval of the war. Approval of a government's handling of the economy is highly correlated with perceptions of the national economy.

23 Table S1 presents univariate statistics on these variables. They show little difference in the two countries in mean approval of the War in Iraq and the war on terror and in relative feelings toward the two leaders. However, the US public evinces lower economic approval than the British.

${ }^{24}$ To test $H 3$ fully, I also examine differences in the parameters of the models by party identification, that is, interaction effects.

25 "Exogenous" variable in structural equation models describes variables from which paths emanate but that are not influenced by other variables in the model; it is not intended to make the claim that "exogenous" variables are entirely uncorrelated with each other, nor to preclude the possibility of any reciprocal influence from variables further along the causal chain. Indeed, there is debate about whether support for war is a rationalization of partisanship or vote choice, that is, endogenous (Berinsky and Druckman 2007; Gelpi and Reifler 2008; Berinsky 2009). Perceptions of the economy provoke similar controversy (Evans and Andersen 2006; Lewis-Beck et al. 2008). Like Gelpi et al. (2007:170), I treat support for the War in Iraq as causally prior to vote choice. I regard this as reasonable because: (i) the measures of support for the war are from pre-election surveys, while measures of support for war and vote choice taken from the same survey present the greatest danger of spurious relationships; (ii) such reverse causation could not explain the asymmetries hypothesized, such as why a voter for a right-wing party would reason backward to emphasize a leader's strength while a voter for a left-wing party would reason backward to emphasize trust; (iii) in additional analysis (see Tables S4 and S5) I estimated models from the BES that only included respondents who were undecided in the pre-campaign survey, planned to vote for one of the minor parties, or ended up switching preference between the pre-campaign survey and the election (there were too few respondents of these kinds in the ANES). If rationalization from vote choice explains the effects of support for the war one would expect very different estimates for this subsample. However, the analysis shows similar results to those for the whole sample.
} 


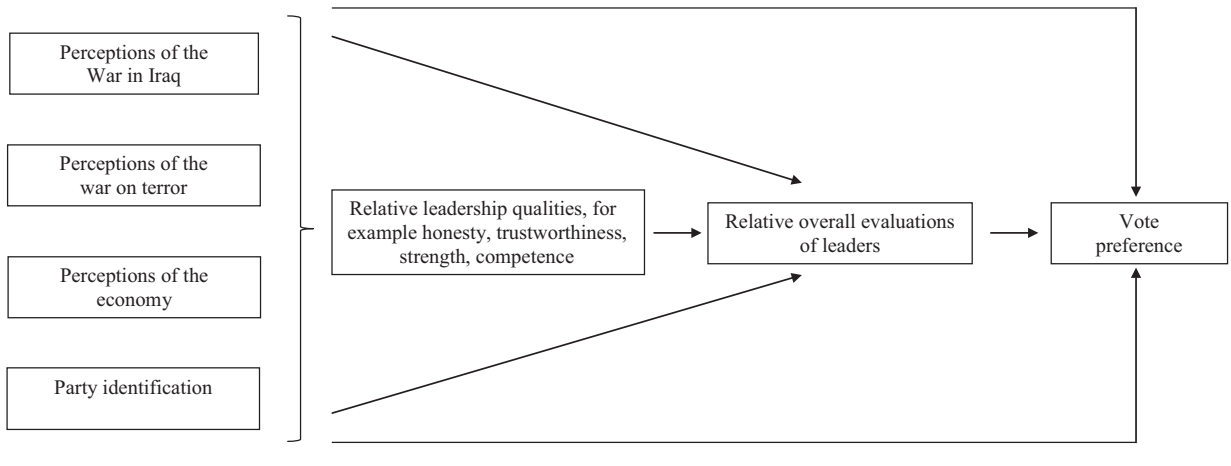

FIG 2. Models of the Influence of the War in Iraq in the United States and Britain

TABLE 2. The Impact of the War in Iraq on Perceptions of Leaders in the 2004 US Election

\begin{tabular}{|c|c|c|c|c|c|c|}
\hline & \multicolumn{5}{|c|}{ Specific leadership qualities } & \multirow[b]{2}{*}{ Overall feeling } \\
\hline & Knowledgeable & Moral & Honest & Cares & Strong & \\
\hline War in Iraq & $.32(.05)^{*}$ & $.31(.04)^{*}$ & $.28(.05)^{*}$ & $.34(.05)^{*}$ & $.33(.05)^{*}$ & $.13(.03)^{*}$ \\
\hline War on terror & $.23(.05)^{*}$ & $.16(.04)^{*}$ & $.21(.05)^{*}$ & $.13(.05)^{*}$ & $.33(.05) *$ & $.13(.02)^{*}$ \\
\hline Economy & $.13(.04)^{*}$ & $.17(.04)^{*}$ & $.13(.04) *$ & $.28(.04)^{*}$ & $.18(.04) *$ & $.08(.02)^{*}$ \\
\hline Democrat & $-.11(.04)^{*}$ & $-.26(.03) *$ & $-.23(.04) *$ & $-.33(.04) *$ & $-.26(.04) *$ & $-.13(.03) *$ \\
\hline Independent & $-.02(.05)$ & $-.12(.05)^{*}$ & $-.08(.05)$ & $-.12(.05) *$ & $-.17(.05)^{*}$ & $-.05(.03)$ \\
\hline Knowledgeable & & & & & & $.10(.02) *$ \\
\hline Moral & & & & & & $.09(.02)^{*}$ \\
\hline Honest & & & & & & $.12(.02)^{*}$ \\
\hline Cares & & & & & & $.26(.03)^{*}$ \\
\hline Strong & & & & & & $.19(.03) *$ \\
\hline Constant & $-.38(.04) *$ & $-.09(.04) *$ & $-.20(.04) *$ & $-.23(.04) *$ & $-.14(.04) *$ & $-.06(.03) *$ \\
\hline
\end{tabular}

(Notes. Coefficients are from structural equation model asymptotic distribution free estimates. Coefficients and standard errors have been rounded to two decimal places. Errors between specific leadership qualities are specified as correlated.

$N=845 ; \chi^{2}=.37$ RMSEA $=.01$ (lower bound $=.000$, upper bound $=.036$; pclose $=.998$ ); Comparative Fit Index $=1.0$.

$* p<.05 ;{ }^{\#} p<.10$ (two-tailed tests).)

Figure 2 also indicates that the models examine their influences on the qualities of the incumbents relative to the principal alternatives-John Kerry in the US and Michael Howard in Britain. ${ }^{26}$ This follows Nadeau, Niemi, and Amato's (1996:248) argument that "leadership evaluations ... are explicitly comparative." Individuals compare the different qualities of leaders, and these qualities affect overall evaluations of leaders to the extent that they perceive differences - seeing a leader as "strong" is unlikely to be an influence if his opponent is seen as equally strong. I operationalize the distinct qualities as the difference in perceptions of Bush and Kerry in the United States and Blair and Howard in Britain, with a positive difference implying a more positive perception of the incumbent. ${ }^{27}$ Overall

\footnotetext{
26 The British models exclude the "valence issues" (Clarke et al. 2009) of perceptions of Labour's handing of the National Health Service, crime, asylum seekers, and taxation. Including these issues shows that they were indeed significant factors in perceptions of the leaders and in vote choice. It also reduces the size of the effects of the war on terror by about half and, considerably, approval of the economy (to zero for its relationship with responsiveness). But they have far less impact on the effects of the War in Iraq and do not lead to different conclusions. No such claims have been made about similar issues and their role in the 2004 US election; moral issues got some attention but careful studies suggest their impact was exaggerated (for example, Hillygus and Shields 2005).

${ }^{27} \mathrm{H} 1$ and $\mathrm{H} 2$ focus on Blair and Howard in Britain because they led the traditionally right-wing and left-wing parties that are the subject of the hypotheses. The Liberal Democrats in 2005 were not a viable party of government and had no longstanding reputation as a hawkish or dovish party. The paper does, however, examine the impact of the War in Iraq on voting Liberal Democrat and the impact of the War in Iraq on Liberal Democrat identifiers.
}

evaluations of the leaders then mediate the effects of specific qualities (Stevens and Karp 2012), with relative overall evaluations of the leaders ultimately affecting vote choice. All variables apart from vote choice come from the pre-election survey in the ANES and from the precampaign survey in the BES rolling cross-section to avoid overestimating relationships via analysis of choices and perceptions gauged at the same time. Hence, I analyze the impact of perceptions and evaluations in September and October in the United States on vote choice in November, while I analyze the impact of perceptions and evaluations in March on the British election in May. ${ }^{28}$ All variables were recoded from zero to one to ease comparison (see Appendix S1 for details).

I begin in Table 2 with the results from the structural equation model for the United States presidential election for influences on leadership qualities and on overall evaluations of the leaders. The diagnostic statistics indicate a strong model, with an upper bound of the RMSEA well below conventional thresholds for good fit and a Comparative Fit Index of 1.0. Focusing on perceptions of the specific leadership qualities of Bush relative to Kerry in the first five columns of results, approval of the War in Iraq had positive and statistically significant influences on perceptions of all five leadership qualities that varied

\footnotetext{
${ }^{28}$ Relative feelings toward the leaders in Britain, drawn from the Wave 2 survey, provide the one exception. Given the causal argument, it makes sense to estimate perceptions of specific qualities in the first wave survey as influences on feelings in the Wave 2 survey. The two-wave ANES survey does not allow this. However, I re-estimated the British models using relative feelings from the Wave 1 survey and it made no difference to the results.
} 
TABLE 3. The Impact of the War in Iraq on Perceptions of Leaders in the 2005 British Election

\begin{tabular}{|c|c|c|c|c|}
\hline & \multicolumn{3}{|c|}{ Specific leadership qualities } & \multirow[b]{2}{*}{ Overall feelings } \\
\hline & Competent & Trustworthy & Responsive & \\
\hline War in Iraq & $.26(.02) *$ & $.34(.02)^{*}$ & $.29(.02)^{*}$ & $.01(.01)$ \\
\hline War on terror & $.30(.02) *$ & $.33(.02)^{*}$ & $.29(.02)^{*}$ & $.04(.01)^{*}$ \\
\hline Economy & $.49(.02) *$ & $.49(.02)^{*}$ & $.28(.02) *$ & $.08(.02) *$ \\
\hline Conservative & $-.41(.01) *$ & $-.54(.01)^{*}$ & $-.36(.01)^{*}$ & $-.11(.01)^{*}$ \\
\hline Liberal Democrat & $.02(.02)$ & $.00(.02)$ & $.01(.01)$ & $-.01(.01)$ \\
\hline Competent & & & & $.18(.02) *$ \\
\hline Trustworthy & & & & $.66(.02) *$ \\
\hline Responsive & & & & $.11(.02) *$ \\
\hline Constant & $-.39(.02) *$ & $-.45(.02) *$ & $-.42(.01)^{*}$ & $.01(.01)$ \\
\hline
\end{tabular}

(Notes. Coefficients are from structural equation model asymptotic distribution free estimates. Coefficients and standard errors have been rounded to two decimal places. Errors between specific leadership qualities are specified as correlated.

$N=4,003 ; \chi^{2}=.00 ;$ RMSEA $=.032$ (lower bound $=.025$, upper bound $=.039 ;$ pclose $=1.00$ ); Comparative Fit Index $=.990$.

${ }^{*} p<.05 ;{ }^{*} p<.10$ (two-tailed tests).)

little. Thus, I do not find an unusually strong relationship between approval of the War in Iraq and perceptions of Bush's relative strength. This contrasts with the performance issues of the war on terror and the economy, for which the size of effects varied quite substantially. The war on terror influenced perceptions of Bush's strength more than his morality or that he cared for people, while approval of the economy affected perceptions of Bush as caring for people to an extent that it did not affect any other quality (at $p<.05$ in Wald tests). ${ }^{29}$

Moving to the final column of results in Table 2, each of the five leadership qualities influenced overall feelings toward the leaders, but seeing Bush as strong or as a leader who cared for people gave him a greater advantage than perceptions of his honesty, knowledge, or morality. The findings for strength in particular confirm that approval of the War in Iraq enhanced perceptions of strength as a quality held by Bush and that this raised evaluations of him, which is consistent with the theory of war as an indicator of performance. And even allowing for these effects, there are still additional direct influences of approval of the War in Iraq (and the war on terror) of about the same size as those from knowledge and morality.

Table 3 shows the estimates for the British election. They have a weaker fit to the data than the US model, but the bounds of the RMSEA and the closeness of the Comparative Fit Index to 1 still indicate a good fit. The results support Hypothesis 1a rather than Hypothesis $1 b$. Approval of the War in Iraq clearly exerted an independent and positive influence on perceptions of the leaders' qualities. The size of effects is also substantial, both similar to those for Bush and similar to those from approval of Labour's handling of the war on terror, though not quite as large as those from the economy (but see footnote ${ }^{26}$ ). In addition, as with the US election, the impact of the War in Iraq does not vary greatly over the leadership qualities. However, similar to perceptions of strength for Bush, its influence is marginally but statistically significantly larger on perceptions of trust than on competence or responsiveness. ${ }^{30}$

\footnotetext{
29 These conclusions do not change if I replace economic approval with retrospective and prospective evaluations of the national economy.

${ }^{30}$ Table 2 also suggests that ignoring the influence of perceptions of the war on terror in the British election of 2005 is an error.
}

Comparison of Tables 2 and 3 also supports Hypothesis 2. The largest effects of the War in Iraq were on perceptions of Bush's strength, and strength was second only to caring about "people like you" in overall feelings toward him, with qualities like honesty and knowledge of lesser importance. ${ }^{31}$ In contrast, perceptions of trustworthiness exerted the largest influence on feelings toward the leftwing leader Blair, dwarfing the impact of perceptions of his competence or responsiveness (which comes closest to the ANES trait of caring).

Figure 3 further illustrates the substantive meaning of the key results. It displays the results of simulations in which approval of the War in Iraq was set at its minimum or maximum while all other variables were at their mean levels for perceptions of Bush's relative strength and honesty, and Blair's relative trustworthiness and competence. I then simulated the influence of perceptions of these qualities on overall feelings toward the leaders. The graphs for the two leaders' qualities and the figures for overall feelings have the same scales for ease of comparison. They confirm $\mathrm{H} 2$ but illustrate that the way in which war affected evaluations of the two leaders was not so much because approval had stronger effects on perceptions of particular qualities than because perceptions of Bush's strength and Blair's trustworthiness weighed particularly heavily in overall evaluations of them. Seeing Bush as a much stronger leader than Kerry moved a respondent from marginally more positive about Kerry to a 30-point advantage for Bush-thermometer ratings like $60-30$ or $70-40$ - whereas seeing Bush as a much more honest leader than Kerry translated to a mere 10-point advantage-ratings like $60-50$ or $50-40$. This presents clear contrasts with Blair. While the impact of perceptions of Blair's competence falls between those of honesty and strength for Bush, judgments of his trustworthiness moved a respondent from a strong preference for Howard when Blair was deemed least trustworthy-feeling thermometer scores of $60-0$ or $70-10$ - to a strong preference for Blair when he was deemed most trustworthyfeeling thermometer scores of $70-0$ or $80-10$ in Blair's favor. Perceptions of Blair's competence or responsiveness, or of Bush's honesty for that matter, simply did not move respondents in the same numbers.

31 These differences in coefficients are statistically significant at $p<.05$ in Wald tests. 
Bush

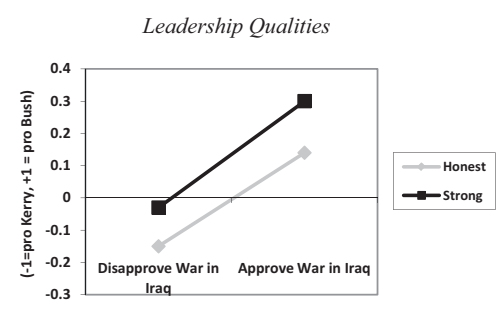

Leadership Qualities

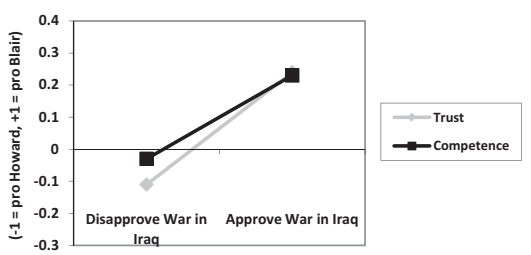

Overall Feelings

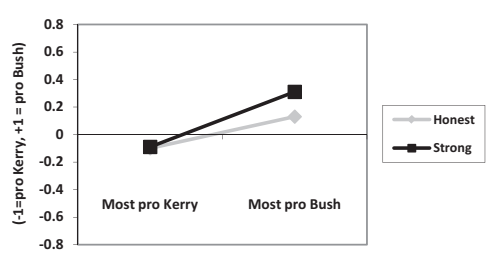

Blair

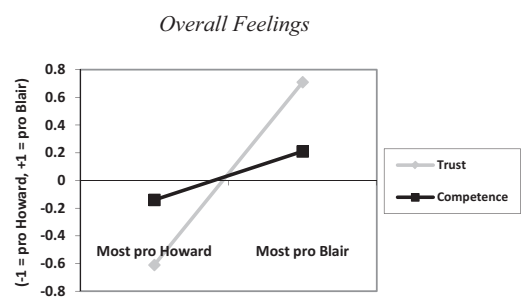

FIG 3. Simulations of the Effects of War on Perceptions of Bush and Blair's Qualities

The analysis so far demonstrates that war played out similarly in the United States and Britain in terms of the direction and size of its effects as a performance issue on perceptions of leaders' qualities but that those qualities were weighted differently in overall evaluations of the leaders. The next stage of analysis, in Table 4, shows the impact of the War in Iraq on vote preferences in the two elections (the excluded category is not voting). ${ }^{32}$ These estimates allow evaluation of the claim that approval of a war asymmetrically affects support for right-wing and leftwing governments. The analysis in Table 4 provides some initial evidence for the hypothesis. Approval of the War in Iraq had positive direct effects on support for Bush and negative for support for Kerry, whereas the effects were positive for both the Labour and Conservative parties in Britain, ${ }^{33}$ although the size of effects of leadership evaluations in the two elections was similar. Simulations of the maximum effects of voting for the incumbent government holding other variables constant indicate larger direct effects of approval of the war in the US election than in the British election, raising the probability of voting for Bush by 13 points and for Blair by 9 points. This accords with the hypothesis that left-wing governments reap smaller rewards from approval of a war. The total effects of approval of the War in Iraq, that is, the combination of direct effects and indirect effects of the war mediated by leadership qualities, indicate a boost in the probability of voting Bush of 22 points, and a decrease in the probability of voting Kerry of 30 points - a net difference of 52 points. They also indicate a boost in the probability of voting Labour of 23 points, but no overall effect on the probability of voting Conservative-a net difference of 23 points that supports the contention in

\footnotetext{
${ }^{32}$ These are from the same structural equation models as in Tables 2 and 3 - they are shown separately for clarity.

33 See Table S1. It is not that mean levels of approval of the war in Britain were higher than in the United States; they were somewhat lower. It could also be argued that the finding is an artifact of differences in question wording, but note also the positive (albeit statistically insignificant) effect of approval of the war on terror on the probability of voting Conservative, in contrast to the direction of effects for the probability of voting for Kerry.
}

H3 that right-wing parties do not hemorrhage support under left-wing governments that are at war to the same extent that left-wing parties lose support under right-wing governments that are at war.

This provides only initial support for $H 3$, however. Additional evidence can be gained by examining the moderating effects of partisanship. In structural equation models, this involves estimating a model's paths separately for each group of partisans and testing for the differences in parameters. Two findings would confirm the validity of $H 3$ : first, a strong negative effect of approval of the War in Iraq on the likelihood that a Democrat identifier approving of the war would vote for Kerry; second, a minimal, or even positive, effect of approval of the War in Iraq on the likelihood that a Conservative identifier would vote Conservative. Table 5 presents the estimates. ${ }^{34}$

The results provide further support for H3. The upper part of the table looks at the direct effects of the War in Iraq, controlling for its impact on overall feelings toward the leaders. The effects of approval of the war on

\footnotetext{
34 Table S2 shows the full model results. Note that pure Independents are excluded from the US models because their numbers are too small. A "proximity account," in which individuals who approved of the war in Iraq voted for the party closest to them in terms of support for the war, provides an alternative explanation. I find the proximity explanation less persuasive, however, for several reasons: First, it cannot explain the different weights given to leadership qualities (the last column of results in Tables 2 and 3); second, the Democrats and the Conservatives were similar in terms of their rhetoric: Both leaders voted to support the war, later argued that they had been misled, were critical of the conduct of the war on such grounds as the lack of allies for the United States and Britain, but both promised in somewhat vague terms to see it to its conclusion; third, there were also similarities in support between the Democrats and Labour: $57 \%$ of Democratic Senators voted to give George W. Bush authorization to use force against Iraq, while $65 \%$ of Labour MPs voted to permit its government to "use all means necessary" to rid Iraq of its weapons of mass destruction, while Republican Senators and Conservative MPs voted overwhelmingly in favor. In sum, the parallels in support for the war among the major parties in the two countries, both before the war and during the elections, were too close for a proximity explanation to explain the patterns of defection in Tables 4 and 5. Lastly, a proximity explanation would imply that Liberal Democrat identifiers who approved of Labour's handling of the War in Iraq should be as likely to vote Labour as Conservative, whereas a reputational explanation would say they should be more disposed to defect to the Conservatives. The latter is exactly what the full results in Table S2 show.
} 
TABLE 4. The Impact of the War in Iraq on Vote Choice

\begin{tabular}{|c|c|c|c|c|c|}
\hline & \multicolumn{2}{|c|}{ United States } & \multicolumn{3}{|c|}{ Britain } \\
\hline & Republican & Democrat & Labour & Conservative & Liberal Democrat \\
\hline War in Iraq & $.13(.05)^{*}$ & $-.19(.05)^{*}$ & $.11(.02)^{*}$ & $.09(.02)^{*}$ & $-.22(.02) *$ \\
\hline War on terror & $.05(.04)$ & $-.07(.05)$ & $.10(.02) *$ & $.03(.02)$ & $-.07(.03) *$ \\
\hline Economy & $.12(.05)^{*}$ & $-.07(.04)^{\#}$ & $.20(.02)^{*}$ & $-.01(.02)$ & $-.00(.03)$ \\
\hline Democrat & $-.30(.05) *$ & $.19(.05)^{*}$ & & & \\
\hline Independent & $-.29(.06)^{*}$ & $-.03(.05)$ & & & \\
\hline Conservative & & & $-.04(.01)^{*}$ & $.45(.02)^{*}$ & $-.18(.02)^{*}$ \\
\hline Liberal Democrat & & & $-.26(.02) *$ & $-.07(.01)^{*}$ & $.47(.02)^{*}$ \\
\hline $\begin{array}{l}\text { Overall feelings } \\
\text { toward leaders }\end{array}$ & $.25(.04) *$ & $-.30(.05)^{*}$ & $.39(.02) *$ & $-.35(.02)^{*}$ & $.01(.02)$ \\
\hline Constant & $.44(.05)^{*}$ & $.48(.05)^{*}$ & $.13(.02)^{*}$ & $.15(.02)^{*}$ & $.33(.02)^{*}$ \\
\hline
\end{tabular}

(Notes. Coefficients are from structural equation model asymptotic distribution free estimates. Coefficients and standard errors have been rounded to two decimal places.

Estimates are from the same structural equation models as Tables 2 and 3. N's and model fit statistics are provided in those tables. ${ }^{*} p<.05 ;{ }^{*} p<.10$ (two-tailed tests).)

TABLE 5. The Impact of the War in Iraq on the Vote Choice of Party Identifiers

\begin{tabular}{|c|c|c|c|c|c|}
\hline & \multicolumn{2}{|c|}{ United States } & \multicolumn{3}{|c|}{ Britain } \\
\hline & Republican & Democrat & Labour & Conservative & Liberal Democrat \\
\hline \multicolumn{6}{|c|}{ Direct effects of approval of the War in Iraq on } \\
\hline Republican identifiers & $.11(.08)$ & $-.16(.05)^{*}$ & & & \\
\hline Democrat identifiers & $.16(.07)^{*}$ & $-.22(.09) *$ & & & \\
\hline Labour identifiers & & & $.06(.04)$ & $.03(.02)$ & $-.14(.03)^{*}$ \\
\hline Conservative identifiers & & & $-.01(.02)$ & $.11(.05)^{*}$ & $-.10(.03) *$ \\
\hline \multicolumn{6}{|c|}{ Total effects of approval of the War in Iraq on } \\
\hline Republican identifiers & $.24(.08) *$ & $-.21(.05)^{*}$ & & & \\
\hline Democrat identifiers & $.22(.07)^{*}$ & $-.38(.09)^{*}$ & & & \\
\hline Labour identifiers & & & $.17(.04) *$ & $-.02(.01)$ & $-.19(.03) *$ \\
\hline Conservative identifiers & & & $.01(.02)$ & $.03(.05)$ & $-.06(.03)^{\#}$ \\
\hline
\end{tabular}

(Notes. Coefficients are from structural equation model asymptotic distribution free estimates. Coefficients and standard errors have been rounded to two decimal places. Errors between specific leadership qualities are specified as correlated.

Model Fit Statistics

United States: $n=783, \chi^{2}=.58$, RMSEA $=.000$ (lower bound $=.000$, upper bound $=.036$ ) Comparative Fit Index $=1.00$.

Britain: $n=2,709, \chi^{2}=.06$, RMSEA $=.020$ (lower bound $=.000$, upper bound $=.032$ ) Comparative Fit Index $=.990$.

${ }^{*} p<.05 ;{ }^{\#} p<.10$ (two-tailed tests).)

opposition identifiers differed between Democrats in the United States and Conservatives in Britain. In the United States, approval of the war had a strong negative effect on Democrats' likelihood to vote for Kerry and a strong positive effect on their likelihood to vote for Bush. In contrast, the direct effects of approval of the war on Conservative identifiers in the British election were small and statistically significant only for the probability of voting Conservative. The effect was also statistically significantly larger than the effect of approval for Conservative identifiers on the probability of voting Labour, whereas the direct effects for Labour identifiers of approval of the war on voting Labour or Conservative were positive but neither statistically significant nor statistically significantly different. This points again to an asymmetry when the traditionally more hawkish party is the opposition.

The lower half of Table 5 shows the estimates of the total effects of the War in Iraq on vote choice, which combine the direct effects in the upper part of the table with the indirect effects of the war via its influence on perceptions of the specific qualities of the leaders and overall feelings toward them. The estimates reinforce the observed patterns. Democrat identifiers who approved of the war were considerably less likely to vote for Kerry and more likely to vote for Bush. The coefficient for the effect of approval of the war on voting for Kerry is also almost twice the size for Democrats as for Republicans, in line with $H 3$, although the difference in coefficients does not quite reach conventional levels of statistical significance $(p=.13)$. But the results in Britain indicate a clear difference, in which Labour derived no benefit from Conservatives who approved of the war. Labour did, however, receive a boost from its own supporters who approved of the war, increasing the probability of voting Labour by about .17.

Figure 4 puts these results into further perspective by simulating the total effects of the War in Iraq on the probability of voting for the incumbent party or their main opposition. It shows point estimates of these probabilities given approval or disapproval of the war among incumbent and opposition party identifiers. I set approval of the war on terror and the economy at the mean for each group of party identifiers. Estimates are based on first calculating the predicted values for perceptions of the leaders given approval or disapproval of the War in Iraq, then the predicted values for overall feelings about 
us
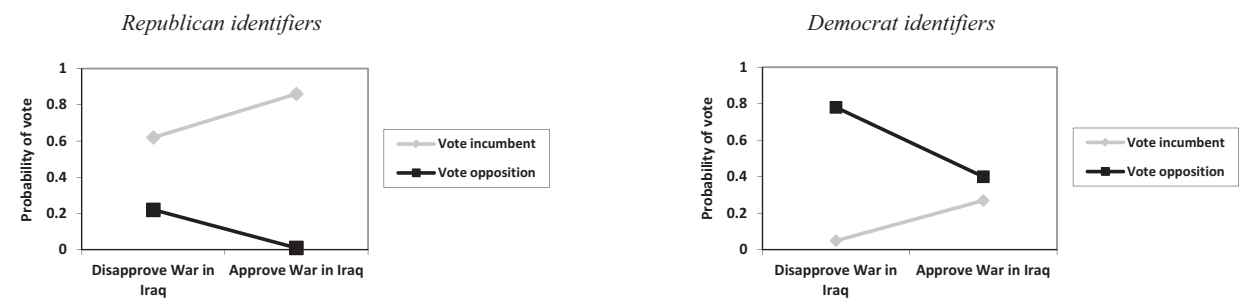

Britain
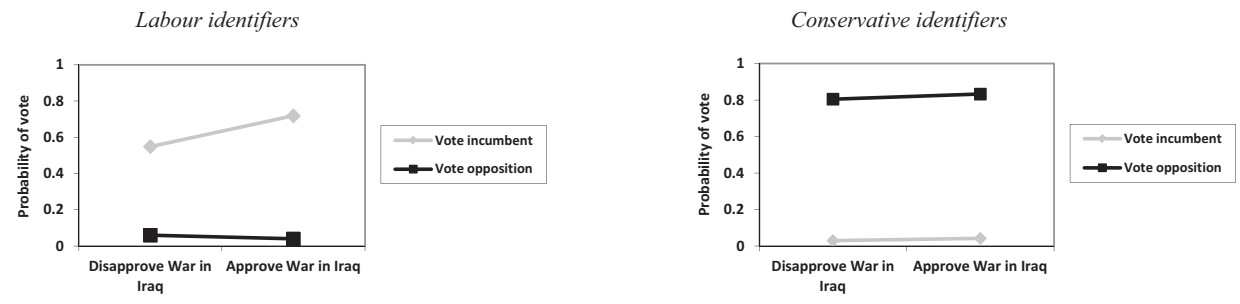

Fig 4. Simulations of the Effects of War on Vote Choice

the leaders given these perceptions and approval or disapproval of Iraq, and then the effect on vote choice given these values for overall feelings about the leaders and approval or disapproval of Iraq.

The results for Democrat identifiers illustrate that, all else equal, differences in approval of the War in Iraq took a respondent from very likely to vote for Kerry to no better than chance. In contrast, disapproval of the war cost Bush votes, but the probability of voting Republican is still .62. The graphs for party identifiers in Britain clearly illustrate the contrast. Conservative identifiers are barely more likely to vote Labour if they approve of the war-the increase in probability is from .03 to $.04 .^{35}$ This is further support for $H 3 .^{36}$

The final piece of analysis pertains to $H 4$, which refers to an asymmetry in distributions of support for war. Table 6 presents evidence, showing approval of the War in Iraq split by party identification. It indicates that opinion was largely polarized along party lines in the United States, with about eight of ten Republicans approving of the war, compared to a similar percentage of Democrats who disapproved. In comparison, Labour identifiers were divided in Britain, with 45 percent of the opinion that Labour had handled the conflict in Iraq poorly. Conservatives were even more likely to disapprove of Labour's

\footnotetext{
${ }^{35}$ Figure 4 may also appear to offer evidence of another asymmetry between right-wing and left-wing parties. Approval of the War in Iraq affected the overall left-wing vote in a way that it did not affect right-wing identifiers: Democrats who approved of the war become less likely to vote Democrat or Republican by .16, while Labour supporters who disapproved of the war become less likely to vote Labour or Conservative by .15. There is no similar pattern among Republicans or Conservatives. However, the different choices available to voters in the two nations made a difference: Cross-pressured Democrats become less likely to vote but cross-pressured Labour identifiers became more likely to vote for the anti-war Liberal Democrats and no less likely to vote overall.

36 This variation in the impact of approval of the war across the two countries is also inconsistent with an alternative explanation that the US public was likely to harbor misperceptions about Iraq (see Kull, Ramsay, and Lewis 20032004), more so than the British public, and that this led to different effects of the war. While it could account for different levels of approval of the war, it cannot explain the variation in impact among those who approved of the war in each country.
}

handling of the war, with $75 \%$ thinking that it had been handled badly, while for the Liberal Democrats, this figure was $83 \%$ - both similar to the levels of Democrat disapproval in the United States. While this confirms H4, it also puts some of the earlier results into perspective. For example, it tempers the large effects of approval of the War in Iraq on the probability of Democrat identifiers defecting to the Republicans because such overwhelming proportions of Democrats did not approve of the war. Conversely, the similar effects of approval of the war on the probability of Republican and Labour identifiers voting to re-elect the incumbent government clearly diverged in net impact when one sees the level of division among Labour identifiers.

\section{Discussion and Conclusion}

This paper uses the War in Iraq as a case to test several hypotheses, both about war as a performance issue in elections and about the moderating effects of the hawkish or dovish reputation of an incumbent party. The analysis confirms the hypothesis that war is a performance issue in elections, much like the economy and other indicators of a government's competence. But the results also show that the effects of war play out differently under right-wing than left-wing governments. The paper fleshes out why wars have a different impact on right-wing than left-wing governments. Although both incumbent governments appeared to pay for the War in Iraq, Blair, the left-wing leader, paid a higher price. The war was not discounted as a performance issue, nor did it have dramatically different effects on perceptions of certain leadership qualities. On one hand, perceptions of strength weighed heavily in evaluations of Bush while other qualities such as honesty were discounted. On the other, perceptions of Blair's trustworthiness became central to evaluations of him. In addition, the war had asymmetric effects on those who identified with the opposition party. Democrats who approved of the war were more likely to defect than Conservatives who approved of the war. By contrast, supporters of the parties who committed to war in the first place were far 
TABLE 6. Party Identification and Approval of the War in Iraq

\begin{tabular}{|c|c|c|c|c|c|c|c|}
\hline & \multicolumn{3}{|c|}{ United States } & & \multicolumn{3}{|c|}{ Britain } \\
\hline & Republicans & Democrats & Independents & & Labour & Conservative & Liberal Democrat \\
\hline \multirow[t]{2}{*}{ Approve } & 79 & 13 & 35 & Handled well & 34 & 14 & 8 \\
\hline & & & & Neither/nor & 20 & 11 & 9 \\
\hline Disapprove & 21 & 87 & 65 & Handled badly & 45 & 75 & 83 \\
\hline$n$ & 477 & 587 & 112 & & 2,376 & 1,592 & 991 \\
\hline
\end{tabular}

(Note. Figures are column \%.)

more likely to approve of the War in Iraq than Labour identifiers. $^{37}$

My comparison of the effects of war on a US and British election broadly implies that similarities in the impact of foreign and domestic affairs on public opinion are not confined to the role of partisanship and elite cues. Just as there are different party stereotypes, and just as partisans have different priorities on domestic economic issues, partisans also have different attitudes toward overseas conflicts. Thus, wars are riskier for a left-wing government with dovish supporters than they are for right-wing governments, because the potential audience costs are greater. Left-wing leaders are not simply more likely to be punished and less likely to be rewarded for going to war; these dynamics play themselves out in their effects on perceptions of leaders. Audiences focus on different aspects of leadership depending on the partisanship of the leader: War affects the influence of perceptions of the attributes of right-wing leaders, such as strength, while undermining support for left-wing leaders by exacerbating the influence of qualities such as trust. The findings also imply that, all else being equal, casualty tolerance will be lower under left-wing leaders because, regardless of perceptions of the likelihood of success, fewer members of the public will consider the leader to have done the right thing. All this suggests, in line with Koch and Sullivan (2010), that left-wing leaders who desire re-election will be less inclined to initiate wars and more disposed to terminate them quickly than right-wing leaders who derive greater benefits from initiating wars. In this sense, left-wing leaders are also more constrained than right-wing leaders.

\section{References}

Abramson, Paul, John Aldrich, Jill Rickershauser, and David Rohde. (2007) Fear in the Voting Booth: The 2004 Presidential Election. Political Behavior 29 (2): 197-220.

Alvarez, R. Michael, Geoffrey Garrett, and Peter Lange. (1991) Government Partisanship, Labor Organization and Macroeconomic Performance. American Political Science Review 85 (2): 539-556.

Baum, Matthew. (2002) The Constituent Foundations of the RallyRound-the-Flag Phenomenon. International Studies Quarterly 46 (2): 263-298.

Baum, Matthew, and Tim Groeling. (2009) Shot by the Messenger: Partisan Cues and Public Opinion Regarding National Security and War. Political Behavior 31 (2): 157-186.

\footnotetext{
${ }^{37}$ While I have argued that the patterns identified generalize beyond Iraq, these hypotheses require additional testing. A third partner in the coalition, Australia, also held an election during this period, with a right-wing incumbent. However, the Australian case is not directly comparable. I provide some explanation, and a discussion and analysis of the election, in the Appendix S1. Despite problems of comparability, the findings are largely supportive of the arguments presented here.
}

Berinsky, Adam. (2009) In Time of War: Understanding American Public Opinion From World War II to Iraq. Chicago, IL: University of Chicago Press.

Berinsky, Adam, and James Druckman. (2007) Public Opinion Research and Support for the Iraq War. Public Opinion Quarterly 71 (1): 126-141.

Bueno de Mesouita, Bruno, Randolph Siverson, and Gary Woller. (1992) War and the Fate of Regimes: A Comparative Analysis. American Political Science Review 86 (3): 638-646.

Chiozza, Giacomo, and H. E. Goemans. (2004) International Conflict and the Tenure of Leaders: Is War Still Ex Post Inefficient? American Journal of Political Science 48 (3): 604-619.

Clarke, Harold, William Mishler, and Paul Whiteley. (1990) Recapturing the Falklands: Models of Conservative Popularity, 1979-83. British Journal of Political Science 20 (1): 63-81.

Clarke, Harold, David Sanders, Marianne Stewart, and Paul Whiteley. (2009) Performance Politics and the British Voter. Cambridge, UK: Cambridge University Press.

Cotтon, Tiмотнy. (1986) War and American Democracy: Electoral Costs of the Last Five Wars. Journal of Conflict Resolution 30 (4): 616635.

Croco, Sarah. (2011) The Decider's Dilemma: Leader Culpability, War Outcomes, and Domestic Punishment. American Political Science Review 105 (3): 457-477.

Debs, Alexandre, and H. E. Goemans. (2010) Regime Type, the Fate of Leaders, and War. American Political Science Review 104 (3): 430-445.

Evans, Geoffrey, and Robert Andersen. (2006) The Political Conditioning of Economic Perceptions. Journal of Politics 68 (1): 194-207.

Garrett, Geoffrey. (1998) Partisan Politics in the Global Economy. Cambridge, UK: Cambridge University Press.

Gaubatz, Kurt Taylor. (1991) Election Cycles and War. Journal of Conflict Resolution 35 (2): 212-244.

Gelpi, Christopher, and Jason Reifler. (2008) Reply to Berinsky and Druckman: Success Still Matters. Public Opinion Quarterly 72 (1): 125-133.

Gelpi, Christopher, Jason Reifler, and Peter Feaver. (2007) Iraq the Vote: Retrospective and Prospective Foreign Policy Judgments on Candidate Choice and Casualty Tolerance. Political Behavior 29 (2): 151-174.

Gershroff, Amy, and Shana Kushner. (2005) Shaping Public Opinion: The 9/11 Iraq Connection in the Bush Administration's Rhetoric. Perspectives on Politics 3 (3): 525-537.

Goddard, Peter, Piers Robinson, and Katy Parry. (2008) Patriotism Meets Plurality: Reporting the Iraq War in the British Press. Media, War E Conflict 1 (1): 9-30.

Hillygus, D. Sunshine, And Todd Shields. (2005) Moral Issues and Voter Decision Making in the 2004 Presidential Election. PS: Political Science and Politics 38 (2): 201-210.

Jentleson, Bruce. (1992) The Pretty Prudent Public: Post Post-Vietnam American Opinion on the Use of Military Force. International Studies Quarterly 36 (1): 49-73.

Koch, Michael, and Patricia Sullivan. (2010) Should I Stay or Should I Go Now? Partisanship, Approval, and the Duration of Major Power Democratic Military Interventions. Journal of Politics 72 (3): 616-629.

Krosnick, Jon, and Laura Brannon. (1993) The Media and the Foundations of Presidential Support: George Bush and the Persian Gulf Conflict. Journal of Social Issues 49 (4): 167-182. 
Kull, Steven, Clay Ramsay, and Evan Lewis. (2003-2004) Misperceptions, the Media, and the Iraq War. Political Science Quarterly 118 (4): 569-598.

Lanoue, David, and Barbara Headrick. (1998) Short-Term Political Events and British Government Popularity: Direct and Indirect Effects. Polity 30 (3): 417-433.

Larson, Eric. (1996) Casualties and Consensus: The Historical Role of Casualties in Domestic Support for U.S. Wars and Military Operations. Santa Monica, CA: Rand Corporation.

Lewis-Beck, Michael, William Jacoby, Helmut Norpoth, and Herbert Weisberg. (2008) The American Voter Revisited. Ann Arbor, MI: University of Michigan Press.

McAllister, IAN. (2006) A War Too Far? Bush, Iraq, and the 2004 U.S. Presidential Election. Presidential Studies Quarterly 36 (2): 260-280.

Merolla, Jennifer, And Elizabeth Zechmeister. (2009) Democracy Under Stress: Crises, Evaluations, and Behavior. Chicago, IL: University of Chicago Press.

Miller, David, Ed. (2004) Tell Me Lies: How the Media Mis-Reported and Distorted the Attack on Iraq. London: Pluto Press.

Mueller, John. (1971) Trends in Popular Support for the Wars in Korea and Vietnam. American Political Science Review 65 (2): 358-375.

Mueller, John. (1973) War, Presidents, and Public Opinion. New York, NY: Wiley.

Mueller, John. (2005) Force, Legitimacy, Success, and Iraq. Review of International Studies 31 (S1): 109-125.

Mughan, Anthony. (1993) Party Leaders and Presidentialism in the 1992 British Election: A Postwar Perspective. In British Elections and Parties Yearbook, edited by David Denver, Colin Rallings, and David Broughton. London, UK: Harvester Wheatsheaf.

Nadeau, Richard, Richard Niemi, and Timothy Amato. (1996) Prospective and Comparative or Retrospective and Individual? Party Leaders and Party Support in Britain. British Journal of Political Science 26 (2): 245-258.

Norpoth, Helmut. (1987) Guns and Butter and Government Popularity in Britain. American Political Science Review 81 (3): 949-959.

Pan, Zhongdang, and Gerald Kosicki. (1994) Voters' Reasoning Processes and Media Influences During the Persian Gulf War. Political Behavior 16 (1): 117-156.

Parker, Suzanne. (1995) Toward an Understanding of 'Rally' Effects: Public Opinion in the Persian Gulf War. Public Opinion Quarterly 59 (4): 526-546.

Rahn, Wendy. (1993) The Role of Partisan Stereotypes in Information Processing About Political Candidates. American Journal of Political Science 37 (2): 472-496.
SAnders, David. (1993) Why the Conservative Party Won-Again. In Britain at the Polls 1992, edited by Anthony King. Chatham, NJ: Chatham House.

Sanders, David, Hugh Ward, And David Marsh. (1987) Government Popularity and the Falklands War. British Journal of Political Science 17 (3): 281-313.

Sanders, David, Harold Clarke, Marianne Stewart, and Paul Whiteley. (2007) Does Mode Matter for Modelling Political Choice? Evidence From the 2005 British Election Study. Political Analysis 15 (3): 257-285.

Stanley, Elizabeth. (2009) Paths to Peace: Domestic Coalition Shifts, War Termination and the Korean War. Stanford, CA: Stanford University Press.

Stevens, Daniel, And JefFrey Karp. (2012) Leadership Traits and Media Influence in Britain. Political Studies 60 (4): 787-808.

Stewart, Marianne, and Harold Clarke. (1992) The (Un)importance of Party Leaders: Leader Images and Party Choice in the 1987 British Election. Journal of Politics 54 (2): 447-470.

Trager, Robert, and Lynn Vavreck. (2011) The Political Costs of Crisis Bargaining: Presidential Rhetoric and the Role of Party. American Journal of Political Science 55 (3): 526-545.

Webb, Paul. (2005) The Continuing Advance of the Minor Parties. In Britain Votes 2005, edited by Pippa Norris, and Christopher Wlezien. Oxford, UK: Oxford University.

\section{Supporting Information}

Additional Supporting Information may be found in the online version of this article:

Appendix S1. Coding of Variables.

Table S1. Univariate Statistics for Variables Used in Models (Mean Scores).

Table S2. Party Identification and the Impact of the War in Iraq in the US.

Table S3. Party Identification and the Impact of the War in Iraq in Britain.

Table S4. The Impact of the War in Iraq in Britain.

Table S5. Party Identification and the Impact of the War in Iraq in Britain.

Figure S1. Approval/Satisfaction with George W. Bush, Tony Blair, and John Howard from October 2001 to May 2005. 